\title{
Analisis Peranan Penanaman Modal Dalam Negeri (PMDN) Dan Penanaman Modal Asing (PMA) Serta Pengaruhnya Terhadap Kesempatan Kerja Dalam Perekonomian Di Propinsi Jambi Periode 1990-2008
}

\author{
oleh : \\ *) Ardi Afrizal \\ **) Sekolah Tinggi Ilmu Ekonomi Muhammadiyah Jambi
}

\begin{abstract}
Abstrak
Rekomendasi yang dapat diberikun adalah sebagai berukut: 1). Diharapkan PMDN dan PMA dapat menunjukkan pertumbuhan yang positif karena pertumbuhan tersebut berindikasi kondisi perekonomian mengalami peningkatan yang debih baik sehingga dapat wempengaruhi peningkatan tingkat pendapatan masyarakat. 2). Diharapkan faktor faktor yang mempengaruhi PMDN dan PMA dengan menggunakan empat variabel seperti kurs, suku bunga pinjaman, tingkat upah dan kebyakan pemerintah mampu berpengaruh positif dan signifikan sehingga PMDN dan PMA tersebut memiliki kontribusi yang besar terhadap pertumbuhan ekonomi di Provinsi Jambi. 3). Pengaruh PMDN dan PMA terhadap pertumbuhan ekonomi dan kesempatan kerja di Provinsi Jambi diharapkan positif dan signifikan sehingga memiliki efek terhadap peningkatan tingkat pendapatan dan kesejahteraan masyarakat yang berkualitas dan pada akhirnya dapat mengurangi tingkat pengangguran.
\end{abstract}

Kata Kunci: PMDN, PMA. Investasi, Pertumbuhan Ekonomi

\section{PENDAHULUAN}

Latar Belakang

Perekonomian Indonesia yang menekankan pertumbuhan ekonomi tinggi ternyata memang rentan pada kemampuannya menetralisir efek negatif dari globalisasi dan gejolak pasar internasional. Ketidaksiapan Indonesia dengan kompetensi sumber daya manusia yang kompeten, ditambah dengan tidak berperannya sistem hukum, politik dan sosial yang dapat menyikapi berbagai kesempatan dari keterbukaan ekonomi ini, semuanya ini sangat berperan dalam menciptakan prestasi semu dari pembangunan Nasional. Untuk mencapai pertumbuhan ekonomi tersebut, penanaman modal atau investasi sangat penting, karena sumber pembentukan modal yang paling efektif adalah tabungan domestik, namun akibat rendahnya pembentukan modal di Indonesia maka untuk pembiayaan investasi, peranan ekspor dan investasi asing sangat dibutuhkan.

Investasi yang lazim disebut dengan istilah penanaman modal atau pembentukan modal merupakan salah satu komponen yang mempengaruhi tingkat pengeluaran agregat. 
Pengeluaran dalam perekonomian terdiri dari pengeluaran rumah tangga, investasi oleh Perusahaan, dan pengeluaran ekspor impor. Dengan demikian naik turunnya tingkat kegiatan ekonomi oleh perubahan masing-masng faktor atau gabungan dari faktor-faktor tersebut. Namun masing-masing faktor mempunyai pengaruh yang berbeda didalam mempengaruhi fluktuasi ekonomi yang berlaku dari waktu ke waktu.

Provinsi Jambi dalam kerangka regional menghubungkan lintas tengah dan lintas timur sumatera yang merupakan jalur distribusi utama yang memiliki keunggulan komparatif dan sangat berpotensi menjadi simpul perdagangan regional, karena letak geografisnya yang sangat mendukung. Disamping aksesnya yang mudah ke kota-kota utama di Sumatera, Provinsi Jambi juga berdekatan dengan pusat pertumbuhan regional Batam, Singapura dan Johor. Oleh karenanya, dimasa yang akan datang, daerah ini diproyeksikan akan sangat berpeluang memainkan peranan penting sebagai daerah pendukung utama (main hinterland) dalam kerja sama ekonomi regional Anonim, (2009).

Salah satu faktor yang mempengaruhi pertumbuhan ekonomi adalah investasi, karena investasi merupakan penenaman modal, berupa PMDN dan PMA. Demikian PMDN di Provinsi Jambi telah memberikan pertumbuhan yang berfluktuasi dengan rata-rata pertumbuhan sebesar 11,64 persen selama 19 tahun terakhir yaitu tahun 1990 hingga tahun 2008 dengan total rata-rata PMDN sebesar Rp.5.355.071 Juta, hingga PMDN tersebut pernah mengalami pertumbuhan yang cukup tinggi pada tahun 1993 sebesar 66,83 persen, namun pada tahun 1996 PMDN mengalami defisit hingga negatif sebesar 47,12 persen dengan total PMDN Rp.1.781.244 Juta di banding pada tahun 1995 pertumbuhan PNDN positif 10,31 persen dengan total PMDN sebesar Rp.2.620.648 Juta. Peningkatan PMDN tersebut di ikuti dengan fluktuasi pertumbuhan PMA, karena PMA merupakan komponen pelengkap yang dapat mempengaruhi pertumbuhan ekonomi, namun pertumbuhan rata-rata PMA di Provinsi Jambi selama 19 tahun terakhir yaitu dari tahun 1990 hingga tahun 2008 tidak mengalami pertumbuhan bahkan negatif sebesar 23,37 persen dengan total rata-rata PMA sebesar Rp. 119.679.593,2 hal tersebut mengindikasikan bahwa PMA secara rata-rata tidak berpengaruh positif terhadap perekonomian di Provinsi Jambi selama 19 tahun terakhir, sementara itu PMA pernah mengalami laju pertumbuhan positif pada tahun 2006 sebesar 74,'78 persen dengan nilai tukar berada pada level Rp.2.383 per dolar AS, kemudian diikuti dengan tingkat suku bunga sebesar 15,2 persen. 
Tingkat upah di Provinsi Jambi terdiri dari dua bentuk yaitu upah minimum regional (UMR) yaitu dari tahun 1990 hingga tahun 2000 dan upah minimum provinsi (UMP) dihitung dari tahun 2000 sampai dengan 2008. Kemudian tingkat upah minimum regional (UMR) mengalami peningkatan perdua tahun sedangkan tingkat upah minimum provinsi (UMP) mengalami peningkatan pertahun. Tingkat upah tersebut cenderung mengalami peningkatan dari tahun ke tahun, seperti tahun 1990 tingkat upah sebesar Rp.245.000, dan kemudian tahun 2008 meningkat menjadi sebesar Rp.724.000, perbulan.

\section{Tujuan penelitian}

Bahwa berdasarkan permasalahan dalam penelitian ini, maka terdapat tujuan dan manfaat yang harus dikemukakan sebagai berikut:

a. Untuk menganalisis pekembangan PMDN dan PMA di Provinsi Jambi periode 19902008.

b. Untuk menganalisis faktor-faktor yang mempengaruhi PMDN dan PMA di Provinsi Jambi periode 1990-2008.

c. Untuk menganalisis pengaruh PMDN dan PMA terhadap pertumbuhan ekonomi dan kesempatan kerja di Provinsi Jambi periode 1990-2008.

\section{TINJAUAN PUSTAKA}

\section{Tcori Pertumbuhan Ekonomi}

Pertumbuhan ekonomi berarti perkembangan dalam perekonomian yang menyebabkan barang dan jasa yang diproduksikan dalam masyarakat meningkat. Dalam analisis makro ekonomi tingkat pertumbuhan ekonomi yang dicapai diukur dari perkembangan pendapat nasional riil yang dicapai pada periode tertentu. Untuk menilai prestasi pertumbuhan ekonomi haruslah terlebih dahulu dihitung pendapat nasional riil, yaitu PNB atau PDB yang dihitung menurut harga-harga yang berlaku dalam tahun dasar. Nilai yang diperoleh dinamakan PNB stau PDB menurut harga tetap, yaitu harga yang berlaku dalam tahun dasar. Tingkat (persentase) pertumbuhan ekonomi dihitung dari pertambahan PNB atau PDB yang berlaku dari tahun ketahun,

Menurut Lipsey (1993), para ekonomi klasik menganut teori pertumbuhan yang relative sederhana, karena mereka memandang adanya suatu mekanisme tunggal (akumulasi modal), sebagai suatu yang penting dan menentukan. Penganut teori modern mulai dengan 
mengenali sejumlah faktor yang mempengaruhi pertumbuhan, dan tidak satupun diantara faktor-faktor tersebut dianggap dominan yaitu:

- Jumlah Modal per Tenaga Kerja

- Kualitas Modal

- Kualiatas Tenaga Kerja

- Perubahan Struktural

- Pertimbangan Institusional

Pertumbuhan ekonomi merupakan usaha-usaha untuk meningkatkan produksi barang dan jasa-jasa di bidang yang semakin meluas dalam masyarakat. Pertumbuhan ekonomi bersangkut paut dengan proses peningkatan produksi barang dan jasa dalam kegiatan ekonomi masayarakat. Dapat dikatakan bahwa pertumbuhan ekonomi menyangkut perkembangan yang berdimensi tunggal dan di ukur dengan meningkatnya hasil produksi dan pendapatan. Dalam pertumbuhan ekonomi, biasanya di telaah proses produksi yang melibatkan sejumlah jenis produk dengan menggunakan sejumlah sarana produksi tertentu. Dalam hubungan ini di ditunjukan hubungan perimbangan kuantitatif antara sejumlah sarana produksi di satu pihak hasil seluruh produksi di pihak lain. Djojohadikusumo, (1994).

\section{Sumber Pertumbuhan Ekonomi}

Output barang dan jasa yang dihasilkan oleh suatu perekonomian bergantung pada kuantitas input yang tersedia, seperti kapital dan tenaga kerja serta produktivitas input tersebut. Sumber-sumber penyebab timbulnya pertumbuhan ekonomi:

1. Jumlah dan kualitas SDA.

2. Jumlah dan kualitas SDM.

3. Supply atau persediaan barang-barang modal.

4. Teknologi.

Faktor-faktor yang mempengaruhi pertumbuhan ekonomi Sukirno, (2005).

1. Kestabilan politik.

2. Kebijakan ekonomi pemerintah.

3. Kekayaan alam yang dimiliki.

4. Jumlah dan kemampuan tenaga kerja.

5. Tersedianya usahawan yang gigih.

6. Kemampuan mengembangkan dan menggunakan teknologi modern. 


\section{Teori Produk Domestik Regional Bruto}

Selanjutnya Djoyohadikusumo, (1994) menyatakan PDRB merupakan jumlah keseluruhan produk yang dihasilkan suatu wilayah selama satu periode dimana jumlah barang-barang dan jasa yang dihasilkan tersebut dinilai dengan uang atas harga pasar yang sedang berjalan. Jadi pada umumnya perhitungan pendapatan regional didasarkan pada harga berlaku, inflasi belum dieleminir sehingga kenaikan pendapatan yang diterima oleh faktorfaktor produksi dari waktu ke waktu belum tentu kenaikan riil. Oleh sebab itu perhitungan pendapatan regional juga dihitung berdasarkan harga konstan guna melihat kenaikan riil dari henaikan nilai produksi suatu daerah.

Ada dua pendekatan dalam perhitungan yaitu metode perhitungan langsung dan tidak langsung. Dalam metode perhitungan secara langsung digunakan data daerah sehingga hasil perhitungannya memperlihatkan produk jasa yang dihasilkan di daerah tersebut. Metode ini dapat dilakukan dengan tiga macam pendekatan yaitu:

1. Pendekatan produksi

Dalam menggunakan metode ini dilakukan dengan mengalikan jumlah barang/jasa yang diproduksi seluruh sektor ekonomi dengan harga barang dan jasa tersebut. Nilai tambah barang dan jasa diperoleh dengan mengurangkan biaya antara dari masingmasing output sektor tersebut.

2. Pendekatan Pendapatan

Yaitu perhitungan nilai tambah dari setiap kegiatan ekonomi yang diperkirakan dengan menjumlah semua balas jasa faktor produksi, seperti upah dan gaji, surplus usaha, penyusutan dan pajak tak langsung neto. Metode perhitungan ini banyak dilakukan pada sektor yang produksinya berupa jasa.

3. Pendekatan pengeluaran

Pendekatan dari sisi pengeluaran bertitik tolak pada penggunaan akhir barang dan jasa yang diproduksi di dalam negeri. Pendekatan ini pengeluaran ini digunakan untuk menghitung PDRB menurut sudut penggunaan.

\section{Teori Investasi}

Investasi, yang lazim disebut juga dengan istilah penanaman modal atau pembentukan modal awal merupakan komponen kedua yang menentukan tingkat pengeluaran agregat. Investasi adalah pengeluaran atau pengeluaran penanaman modal atau perusahaan untuk membeli barang-barang modal dan perlengkapan-perlengkapan produksi untuk menambah 
kemampuan memproduksi barang-barang dan jasa jasa yang tersedia dalam perekonomian Sukirno, (2005). Investasi adalah bagian dari total pendapatan nasional (national income) atau pengeluaran Nasional (national expenditure) yang khusus diperuntukan memproduksi barang-barang capital atau modal pada suatu periode tertentu. Sedangkan istilah investasi bruto mengacu pada pengerluaran total untuk barang-barang modal yang baru, sementara investasi neto berarti tambahan barang modal yang dihasilkan setelah dikurangi yang rusak atau haus karena dipakai dan membutuhkan pengganti (Tan, 2004).

Ada beberapa teori tentang investasi diantaranya:

1. Teori Klasik

2. Teori Investasi Keynes

3. Teori Akselarator

4. Teori Neo Klasik

5. Teori Investasi Tobin

Investasi merupakan pengeluaran yang ditujukan untuk meningkatkan atau sempertahankan stok barang modal (meliputi: pabrik, mesin, kantor, dan produk tahan lama lainnya yang digunakan dalam proses produksi) digolongkan dalam investasi tetap perusahaan, investasi tempat tinggal, dan investasi persediaan. Sementara Manurung, (2002). ivestasi adalah pengeluaran-pengeluaran yang meningkatkan jumlah barang modal (stok barang modal) dalam suatu perekonomian pada suatu waktu tertentu. Di bagian lain Tandeilin, (2001) mengemukakan investasi adalah komitmen atas sejumlah dana atau sumber daya lainnya yang dilakukan pada saat ini, dengan tujuan memperoleh sejumlah keuntungan dimasa datang.

\section{Pentingnya Investasi Dalam Pertumbuhan Ekonomi}

Pada setiap moment, persediaan modal adalah determinan output perekonomian yang penting, karena persediaan modal bisa berubah sepanjang waktu, dan perubahan itu bisa mengarah ke pertumbuhan ekonomi. Biasanya, terdapat dua. kekuatan yang mempengaruhi persediaan modal, investasi dan depresiasi. Investasi mengacu pada pengeluaran untuk perluasan usaha dan peralatan baru, dan hal itu menyebabkan persediaan modal bertambah. Depresiasi mengacu pada penggunaan modal, dan hal itu menyebabkan persediaan modal berkurang Mankiw, (2000). Pertumbuhan ekonomi sangat tergantung pada tenaga kerja dan jumlah kapital. Investasi akan menambah jumlah daripada kapital. Tanpa investasi maka 
tidak akan ada pabrik/mesin baru, dan dengan demikian tidak ada ekspansi. Pengertian investasi mencakup investasi barang-barang tetap pada perusahaan (business fixed invesment), persediaan (inventory) serta perumahan (residential). Faktor-faktor penentu investasi sangat tergantung pada situasi dimasa depan yang sulit untuk diramalkan, maka investasi merupakan komponen yang paling mudah berubah. Usaha untuk mencatat nilai penanaman modal yang dilakukan dalam satu tahun tertentu yang digolongkan sebagai investasi, meliputi pengeluaran atau pembelanjaan untuk:

a. Seluruh nilai pembelian para pengusaha atas barang modal dan membelanjakan untuk mendirikan industri-industri.

b. Pengeluaran masyarakat untuk mendirikan tempat tinggal.

c. Pertambahan dalam nilai stok barang-barang perusahaan yang berupa bahan mentah, barang yang belum diproses dan barang jadi.

\section{Teori Penanaman Modal Dalam Negeri (FMDN)}

Dari sisi lain investasi dapat juga dibedakan antara investasi dalam negeri atau penanaman modal dalam negeri (PMDN) dan investasi asing yang sering disebut penanaman modal asing (PMA). PMDN merupakan investasi yang dilakukan oleh investor dalam negeri, sementara PMA investasi yang dilakukan oleh investor asing dengan menanamkan modal proyek investasi di Indonesia. PMA tersebut dapat juga mengikutsertakan penanaman modal dari investasi domestik dengan memberi sekian persen dari total investasi tersebut.

\section{Penanaman Modal Asing (PMA)}

Tiga faktor yang menjadi penarik mengalirnya arus PMA, dari suatu negara ke negara adalah:

1. Investor harus memiliki keuntungan, kepemilikan atas saingan-saingannya di negara tuan rumah. Keuntungan kepemilikan tersebut bisa dalam bentuk hak monopoli atas suatu produk, teknologi yang unik dan canggih, pengetahuan pasar, atau teknik pemasaran yang lebih baik.

2. Negara tuan rumah harus memiliki keuntungan lokasi yang menarik bagi investor. Hal ini bisa dalam bentuk pasar domestik yang besar dan potensial pertumbuhannya, tenaga kerja yang murah yang melimpah, sumber daya alam yang melinnpah, biaya 
transportasi yang rendah dan insentif yang diberikan oleh pemerintah negara tuan rumah.

3. Harus ada keuntungan internalisasi yang akan mendorong investor untuk memilih menanamkan modalnya secara langsung daripada menanamkan modal dalam bentuk perjanjian-perjanjian lisensi lainnya. Ketertarikan seorang investor dalam memilih lokasi untuk menanamkan modalnya tergantung dari tipe perusahaan investasi tersebut. Sebagai contoh, untuk perusahaan yang bergerak dibidang pengelolaan sumber daya alam, maka lokasi yang akan dipilihnya adalah lokasi yang memiliki sumber daya alam yang melimpah. Dalam hal ini keuntungan kepemilikan dari perusahaan tersebut adalah produk padat modal dan teknologi yang cukup tinggi. Pada kasus ini keuntungan internalisasi mungkin tidak begitu kuat; dan negara tuan rumah dapat melakukan negosiasi kepemilikan dengan investor perusahaan tersebut dalam hak kepemilikan, misalnya: dengan bentuk kontrak kerja sama.

Dalam teori siklus produksi hampir semua produk mengalami siklus produksi dan PMA merupakan siklus dari produksi tersebut siklus produksi akan dijelaskan tahapannya sebagai berikut:

1. Tahap Inovasi

2. Tahap Pertumbuhan

3. Tahap Kematangan Produk

\section{Teori Kesempatan Kerja}

Adapun intervensi pemerintah dalam kesempatan kerja antara lain:

1. Inti teori ekonomi makro yang dikemukakan J.M. Keynes adalah kecenderungan konsumsi (dipihak lain berarti kecenderungan menabung), efisiensi kapital marjinal (MEC), dan preferensi likuiditas. Selanjutnya, ketiga prinsip yang pokok ini dilengkapi dengan fungsi-fungsi permintaan, penawaran, dan fungsi produksi. Perilaku orang menabung berbeda dengan perilaku investor, oleh karena itu dapat terjadi jumlah investor yang diperlukan tidak sama dengan jumlah tabungan yang tersedia, atau sebaliknya. Tingkat investasi yang dilakukan tergantung pada MEC, sedangkan tabungan ditentukan oleh tinggi rendahnya,pendapatan.

2. Selanjutnya, penawaran uang tidak hanya untuk keperluan transaksi, pembelian barang maupun jasa, tetapi juga untuk keperluan spekulasi, Permintaan uang untuk 
transaksi tidak ada bedanya dengan yang ditemukan pada pasar uang klasik, tetapi permintaan yang digunakan untuk spekulasi merupakan hal yang baru sama sekali. Namun demikian, komponen yang baru ini telah mendekatkan model pembahasan ke dalam kenyataan ekonomi. Karena fungsi uang bukan semata-mata untuk mediapertukaran, tetapi juga sebagai penyimpan nilai. Dengan demikian, pada suatu waktu, penggunaan untuk spekulasi dapat meningkat, dan kebutuhan uang untuk transaksi dapat terganggu. Misalnya, jika tingkat bunga turun, kecenderungan investasi diperkirakan meningkat, tetapi dengan komponen kedua itu, harga obligasi dapat naik dan menimbulkan kelebihan penawaran. Variabel tabungan tidak dipengaruhi tingkat bunga, tetapi oleh pendapatan, sedangkan investasi yang menciptakan kenaikan pendapatan. Bukan investasi yang tergantung pada pendapatan. Oleh karena itu kegiatan ekonomi dapat mendatangkan resesi depresi. Singkatnya, fungsi investasi itu tidak stabil, sedangkan fungsi tabungan relatif stabil. Dapat terjadi investasi lebih kecil dari tabungan.

3. Pasar tenaga kerja dihadapkan dengan persoalan adanya pengangguran terpaksa yang tidak dapat diselesaikan secara otomatis. Walaupun tingkat upah diturunkan, ada kelompok masyarakat yang tidak bersedia menerima tingkat upah terlalu rendah. Untuk mengatasi ini (karena tabungan tidak cukup untuk investasi), maka permintaan melakukan investasi. Kalau ini terjadi, maka permintaan efektif bangkit dan kecenderungan konsumsi kembali naik. Jadi aspek ( C + I ) merupakan komponen permintaan efektif yang mendorong roda kegiatan ekonomi (Anonim, 2009).

Sebagai bagian dari penduduk tenaga kerja mencakup penduduk umur kerja yang sudah atau sedang bekerja, yang sedang mencari pekerjaan, dan yang melakukan kegiatan lain seperti bersekolah dan mengurus rumah tangga. Secara praktis pengertian tenaga kerja di bedakan hanya oleh batas umur. Tiap-tiap Negara memberikan batas umur yang berbeda. Selain melihat ukusan angkatan kerja (L) tergantung pada ukuran jumlah penduduk yang berusia layak kerja (Age-eligible Population), yaitu (P), dan keseluruhan tingkat partisipasi angkan kerja L/P, persentase penduduk yang berusia layak kerja yang memilih untuk ikut dlam angkatan kerja, jadi:

$$
\mathrm{L}=\mathrm{P}(\mathrm{L} / \mathrm{P})
$$

Masalah tenaga kerja khususnya dinegara-negara yang sedang berkembang (termasuk Indonesia), merupakan masalah yang kompleks meliputi: 
1. Kualitas tenaga kerja yang rendah.

Kualitas sumberdaya manusia yang rendah dinegara-negara yang sedang berkembang adalah rendah dan kurang memiliki mobilitas. Pada umunya mereka tidak memiliki keterampilan, kecakapan dan semangat kerja yang tinggi, karena rendahnya tingkat pendidikan. Bagi yang memiliki pendidikanpun, kebanyakan hanya siap bekerja pada lapangan pekerjaan yang kurang inovatif.

2. Penawaran tenaga kerja yang melebih permintaan tenaga kerja.

Penawaran tenaga kerja yang melebihi permintaan tenaga kerja merupakan masalah dalam pengembangan sumberdaya manusia. Rendahnya tingkat investasi dan rendahnya kualitas tenaga kerja menyebabkan rendahnya permintaan tenaga kerja. Meskipun investasi tinggi tetapi tingkat permintaan tenaga kerja lokal rendah, hal ini disebabkan karena yang dibutuhkan untuk investasi tertentu adalah tenaga kerja yang memiliki kualifikasi tertentu pula.

\section{Hubungan Pembangunan Ekonomi dan Penyerapan Tenaga Kerja}

Upaya pengembangan sumberdaya manusia dan ketenagakerjaan bagi Indonesia sangat penting artinya untuk mengatasi berbagai tantangan yang muncul, khususnya dalam bidang ekonomi, secara umum tantangan yang dihadapi oleh tenaga kerja Indonesia adalah:

1. Tantangan dari dalam terjadi karena transformasi perkembangan ekonomi dalam negeri yang telah mengubah wajah perekonomian dari dominasi negara agraris menjadi secara perlahan industri. Permasalahan yang muncul adalah pada transformasi tenaga kerja dari sektor pertanian ke sektor industri, dan transformasi di dalam sektor industri sendiri dari industri yang mengandalkan pada upah buruh dan keterampilan yang rendah menuju industri yang bertumpu pada kualitas buruh yang berketerampilan tinggi.

2. Tantangan yang berasal dari yang diakibatkan makin kuatnya arus globalisasi yang akan meningkatkan mobilitas arus sumberdaya manusia antarnegara. Arus perdagangan dan investasi menjadi semakin marak dengan terbukanya hubungan antar negara, dimana kawasan Asia, termasuk Indonesia menjadi pusat dinamisator perkembangan tersebut. Dalam dimensi ketenagakerjaan globalisasi telah menciptakan kecenderungan atau trend sebagai berikut: a) Meningkatnya arus investasi asing antar negara bersamaan dengan restrukturisasi, diversifikasi dan 
globalisasi industri akan memberikan da.mpak terhadap perubahan struktur tenaga kerja, b) Perbedaan surplus dan defisit tenaga kerja antar negara akan menciptakan arus tenaga kerja antar negara yang potensial akan menghasilkan transfer keterampilan dan teknologi, c) Perpindahan tenaga kerja akan terjadi pada negaranegara yang memiliki tingkat partisipasi angkatan kerja yang rendah yang disertai dengan tingkat penganggguran dan setengah pengangguran tinggi, d) Negara-negara yang menginjak tahap industrialisasi semakin menyadari pentingnya pendidikan dan latihan serta pengembangan sumberdaya manusia sebagai suatu alat strategis untuk menyukseskan pembangunan.

Disinilah kemudian timbul masalah pasar kerja yang timpang. Dimana pasar kerja di Indonesia ditandai oleh kelebihan tenaga kerja yang tidak terampil yang sangat besar jumlahnya yang disebabkan terutama oleh struktur ekonomi yang belum mampu menyerap angkatan kerja yang ada, yang kenyataannya bertambah setiap tahun. Tetapi dilain pihak diberbagai sektor maupun wilayah terdapat kekurangan tenaga kerja yang terampil dan berkemampuan tinggi. Oleh karena itu masalah dan kebijaksanaan perluasan kesempatan kerja sebenarnya tidak terlepas dari konteks pembangunan secara keseluruhan yang dalam titik tolak dilandasi pemikiran oleh usaha mempertinggi produksi nasional.

\section{Teori Upah}

Pengaturan mengenai upah minimum dijelaskan pada pasal 88-90. Dalam pasal-pasal tersebut dinyatakan bahwa salah satu komponen/ kebijakan pengupahan adalah upah minimum (pasal 88). Pemerintah menetapkan upah minimum berdasarkan kebutuhan hidup layak dan dengan memperhatikan produktivitas dan pertumbuhan ekonomi (pasa188). Upah minimum dietapkan berdasarkan wilayah provinsi atau kabupaten/ kota serta berdasarkan sektor pada wilayah provinsi atau kabupaten/ kota (pasa189). Pengusaha dilarang membayar upah lebih rendah dari upah minimum dan bagi pengusaha yang tidak mampu membayar upah minimum tersebut dapat dilakukan penangguhan (pasal 90). Secara proporsional, kebijakan upah minimum bermanfaat dalam melindungi kelompok kerja marjinal yang tidak terorganisasi di sektor modern. Kenaikan upah minimum yang tinggi dalam kondisi pertumbuhan ekonomi yang rendah di Indonesia belakangan ini telah berdampak, pada turunnya keunggulan komparatif industri-industri padat karya, yang pada gilirannya menyebabkan berkurangnya kesempatan kerja akibat berkurangnya aktivitas produksi. 
Penelitian ini menyusun perangkat komponen kebutuhan hidup layak berikut jenisjenis kebutuhan untuk setiap komponen. Sumber data yang diperoleh dari responden di lapangan terdapat, dari komponen dan jenis kebutuhan hidup minimum yang diajukan kepada responden terdapat lima jenis komponen, yaitu:

- Makanan dan minuman

- Perumahan dan fasilitas

- Sandang

- Kesehatan dan estetika

- Aneka kebutuhan

\section{METODE ANALISIS}

\section{Jenis dan Sumber Data}

Data adalah suatu informasi yang digunakan sebagai alat dalam pengambilan keputusan dan selanjutnya data tersebut dianalisis berdasarkan metode yang diperlukan. Dalam menganalisis data salah satunya adalah data sekunder atau library research, dimana data sekunder adalah data yang di peroleh dalam bentuk sudah jadi berupa publikasi dari data yang sudah di kumpulkan oleh pihak atau instansi lain- Adapun jenis data yang digunakan dalam penelitian ini sebagai berikut:

1. Data PDRB di Provinsi Jambi atas dasar harga konstan 1993 dan 2000 periode 19902008

2. Data PMDN di Provinsi Jambi periode 1990-2008

3. Data PMA di Provinsi Jambi periode 1990-2008

4. Data kurs rata-rata/ tetap Rupiah terhadap Dollar Amerika Serikat periode 1990-2008

5. Data suku bunga pinjaman periode 1990-2008

6. Data kesempatan kerja di Provinsi Jambi periode 1990-2008

7. Data tingkat upah Provinsi di Provinsi Jambi periode 1990-2008

8. Kebijakan pemerintah dalam mempengaruhi investasi di Provinsi Jambi periode 19902008.

Adapun sumber data yang diperoleh dalam penelitian ini sebagai berikut:

a. Badan Pusat Statistik (BPS) di Provinsi Jambi.

b. Bapemproda di Provinsi Jambi.

c. Bank Indonesia (BI) cabang di Provinsi Jambi 
d. Dinsosnaker di Provinsi Jambi

e. Internet

\section{Analisis Data}

Adapun alat analisis yang di gunakan dalam penelitian ini sebagai berikut:

1. Bahwa untuk menjawab permasalah pertama di gunakan rumus pertumbuhan, yaitu untuk menganalisis perkembangan PMDN dan PMA di Provinsi Jambi periode 19902008 dengan formulasi. Sukinno, (2005) sebagai berikut:

$$
P M D N=\frac{P M D N_{12}-P M D N_{11}}{P M D N_{12}} \times 100 \%
$$

Dimana:

PMDN $=$ Penanaman Modal dalam negeri di Provinsi Jambi

$\mathrm{Y}_{\mathrm{t} 1} \quad=$ PMDN Di Provinsi Jambi periode 1990-2008 tahun $\mathrm{t}_{\mathrm{t} 1}$

$\mathrm{Y}_{\mathrm{t} 2}=$ PMDN di Provinsi Jambi periode 1990-2008 tahun $\mathrm{t}_{2}$

$$
P M A=\frac{P M A_{t 2}-P M A_{t 1}}{P M A_{t 2}} \times 100 \%
$$

Dimana :

PMA = Penanaman Modal Asing di Provinsi Jambi

$\mathrm{Y}_{\mathrm{t} 1} \quad=$ PMA Di Provinsi Jambi periode 1990-2008 tahun $\mathrm{t}_{\mathrm{t} 1}$

$\mathrm{Y}_{\mathrm{t} 2}=$ PMA di Provinsi Jambi periode 1990-2008 tahun $\mathrm{t}_{2}$

2. Bahwa untuk menjawab permasalahan kedua yaitu faktor-faktor yang mempengaruhi PMDN dan PMA di Provinsi Jambi perinde 1990-2008 dengan menggunakan rumus persamaan regresi linier berganda. Firdaus, (2004) sebagai berikut:

$$
\begin{gathered}
b=\frac{\left(\Sigma X_{2 t} Y_{t}\right)\left(\Sigma_{X}{ }^{3 t}{ }^{2}\right)-\left(\Sigma_{X 3 t} Y_{t}\right)\left(\Sigma_{X 2 t} X_{3 t}\right)}{\left(\Sigma_{x_{2 t}}{ }^{2}\right)\left(\Sigma_{x_{3 t}}{ }^{2}\right)-\left(\Sigma_{x_{2 t}} X_{3 t}\right)^{2}} \\
S_{e}^{2}=\frac{X_{e i}^{2}}{(n-2)}
\end{gathered}
$$

Berdasarkan formulasi di atas, maka untuk menjawab faktor-faktor yang mempengaruhi PMDN dapat dibuat persamaan fungsi regresi berganda sebagai berikut: 
$\log Y_{\mathrm{PMDN}}=\beta_{0}+\beta_{1} \mathrm{X}_{1}+\log \beta_{2} \mathrm{X}_{2}+\log \beta_{3} \mathrm{X}_{3}+\beta_{4} \mathrm{X}_{4}$

Dimana:

$\log \mathrm{Y}_{\mathrm{PMDN}} \quad=$ PMDN di Provinsi Jambi periode 1990-2008

$\beta_{1} X_{1} \quad=$ Suku bunga pinjaman di Provinsi Jambi periode 1990-2008

$\log \beta_{2} X_{2} \quad=$ Kurs rata-rata di Provinsi Jambi periode 1990-2008

$\log \beta_{3} X_{3} \quad=$ Tingkat upah di Provinsi Jambi periode 1990-2008

$\beta_{4} \mathrm{X}_{4} \quad=$ Kebijakan pemerintah Provinsi Jambi periode 1990-2008

$\beta_{0} \quad=$ Konstanta

$\beta_{1,} \beta_{2,} \beta_{3} \beta_{4}, \quad=$ Parameter (Koefisien estimasi variabel independen)

$\mathrm{Se} \quad=$ Standar error

Berdasarkan formulasi di atas, maka untuk menjawab faktor-faktor yang mempengaruhi PMA dapat dibuat persamaan fungsi regresi berganda sebagai berikut:

$\log Y_{\mathrm{PMA}}=\beta_{0}+\beta_{1} \mathrm{X}_{1}+\log \beta_{2} \mathrm{X}_{2}+\log \beta_{3} \mathrm{X}_{3}+\beta_{4} \mathrm{X}_{4}$

Dimana:

$\log Y_{\text {PMA }} \quad=$ PMA. di Provinsi Jambi periode 1590-2008

$\beta_{1} X_{1} \quad=$ Suku bunga pinjaman di Provinsi Jambi periode 1990-2008

$\log \beta_{2} X_{2} \quad=$ Kurs rata-rata di Provinsi Jambi periode 1990-2008

$1 \log \beta_{3} X_{3} \quad=$ Tingkat upah di Provinsi Jambi periode 1990-2008

$\beta_{4} X_{4} \quad=$ Kebijakan pemerintah Provinsi Jambi periode 1990-2008

$\beta_{0} \quad=$ Konstanta

$\beta_{1,} \beta_{2,} \beta_{3} \beta_{4}, \quad=$ Parameter (Koefisien estimasi variabel independen)

Se $\quad=$ Standar error

3. Bahwa untuk menjawab permasalahan ketiga yaitu bagaimana pengaruh PMDN dan PMA terhadap pertumbuhan ekonomi dan kesempatan kerja di Provinsi Jambi periode 1990-2008 dengan menggunakan rumus persamaan regresi linier sederhana sebagai berikut:

$b=\frac{\Sigma X i Y i-\Sigma X i \Sigma Y i}{n \Sigma X_{i}^{2}-(\Sigma X i)^{2}}$

$S_{e}^{2}=\frac{X_{e i}^{2}}{(n-2)} \quad$ atau $\quad S_{e}^{2}=\frac{\sum Y_{i}^{2}-b^{2} X_{i}^{2}}{n-2}=\frac{\sum Y_{i}^{2}-b \Sigma X_{2} Y_{i}}{n-2}$ 


$$
S_{e}=\sqrt{S_{e}^{2}}
$$

Berdasarkan formulasi di atas, maka untuk menjawab pengaruh PMDN terhadap pertumbuhan ekonomi Provinsi Jambi dapat dibuat persamaan fungsi regresi sederha sebagai berikut:

$\mathrm{Y}_{\text {Pet }}=\beta_{0}{ }^{+} \beta_{1} \mathrm{PMDN}$

Dimana :

$\mathrm{Y}_{\mathrm{PEt}} \quad=$ Pertumbuhan ekonomi di Provinsi Jambi periode 1990-2008

PMDN = Penanaman modal dalam negeri di Provinsi Jambi periode 1990-2008

$\beta_{0} \quad=$ Konstanta

$\mathrm{b}_{1} \quad=$ Parameter (Koefisien estimasi variabel independen)

Se $\quad=$ Standar error

Berdasarkan formulasi di atas, maka untuk menjawab pengaruh PMA terhadap pertumbuhan ekonomi Provinsi Jambi dapat dibuat persamaan fungsi regresi sederha sebagai berikut:

$\mathrm{Y}_{\mathrm{PEt}} \quad=\beta_{0}+\beta_{1} \mathrm{PMA}$

Dimana:

$\mathrm{Y}_{\mathrm{PEt}} \quad=$ Pertumbuhan ekonomi di Provinsi Jambi periode 1990-2008

PMA = Penanaman modal asing di Provinsi Jambi periode 1990-2008

$\beta_{0} \quad=$ Konstanta

$\beta_{1} \quad=$ Parameter (Koefisien estimasi variabel independen)

Se $\quad=$ Standar error

Berdasarkan formulasi di atas, maka untuk menjawab pengaruh PMDN terhadap kesempatan kerja Provinsi Jambi dapat dibuat persamaan fungsi regresi sederha sebagai berikut:

$\mathrm{Y}_{\mathrm{KSt}}=\beta_{0}{ }^{+} \beta_{1} \mathrm{PMDN}$

Dimana:

$\mathrm{Y}_{\mathrm{KSt}} \quad=$ Kesempatan kerja di Provinsi Jambi periode 1990-2008

PMDN = Penanaman modal dalam negeri di Provinsi Jambi periode 1990-2008

$\beta_{0} \quad=$ Konstanta

$\mathrm{b}_{1} \quad=$ Parameter (Koefisien estimasi variabel independen) 
Se $\quad=$ Standar error

Berdasarkan formulasi di atas, maka untuk menjawab pengaruh PMA terhadap kesempatan kerja Provinsi Jambi dapat dibuat persamaan fungsi regresi sederha sebagai berikut:

$\mathrm{Y}_{\mathrm{KSt}}=\beta_{0}{ }^{+} \beta_{1} \mathrm{PMA}$

Dimana:

$\mathrm{Y}_{\mathrm{Kst}} \quad=$ Kesempatan kerja di Provinsi Jambi periode 1990-2008

PMA = Penanaman modal asing di Provinsi Jambi periode 1990-2008

$\mathrm{b}_{1} \quad=$ Parameter (Koefisien estimasi variabel independen)

Se $\quad=$ Standar error

\section{Pengujian Hipotesis}

Untuk menguji hipotesis dapat di lakukan dengan uji statistik sebagai berikut:

\section{Uji F-Statistik}

Untuk melihat masing-masing koefisien independensi secara keseluruhan atau secara bersama terhadap pengaruh PMDN dan PMA di Provinsi Jambi periode -19902008 maka di gunakan uji F-Statistik yaitu dengan membandingkan antara nilai F-hitung dengan F tabel.

Dimana.:

$F=\frac{R /(K-1)}{\left(I-R^{2}\right) /(n-K)}$

Di mana:

$\mathrm{F}=\mathrm{F}$ - hitung

$\mathrm{R}^{2}=$ Koefisien determinasi

$\mathrm{n} \quad=$ Jumlah observasi

$\mathrm{K}=$ Jumlah variabel

Untuk kriteria pengujian F-hitung terhadap F-tabel adalah sebagai berikut:

1. Apabila F-hitung $>$ F-tabel, maka Ho di tolak artinya tidak ada pengaruh

2. Apabila F-hitung $<$ F-tabel, maka Ho di terima artinya tidak ada pengaruh

\section{Uji t-Statistik}


Uji t-Statistik di lakukan untuk menguji keberadaan koefisien yang di taksir sebagai pengaruh antara variabel bebas terhadap variabel terikat, di gunakan uji t-Statistik dengan rumus sebagai berikut:

$$
\begin{aligned}
& t=\frac{b i}{S e}(b i) \\
& \mathrm{t} \quad=\text { t-hitung } \\
& \mathrm{bi}=\text { Koefisien regresi } \\
& \mathrm{Se}=\text { Standar error }
\end{aligned}
$$

Dengan membandingkan t-hitung dan t-tabel pada tingkat keyakinan tertentu dapat di ambil kesimpulan dengan kriteria sebagai berikut:

1. Apabila t-hitung $>$ t-tabel, maka Ho di tolak

2. Apabila t-hitung $<\mathrm{t}$-tabel, maka Ho di terima

\section{HASIL PENELITIAN DAN PEMBAHASAN}

\section{Permbangan PMDN dan PMA di Provinsi Jambi Periode 1990-2008}

Laju pertumbuhan PMDN selama tahun 1990 sampai 2008 dengan rata-rata pertumbuhan 11,64 persen. Pertumbuhan PMDN yang positif akan berdampak terhadap laju perekonomian dalam mempengaruhi tingkat kesejahteraan masyarakat. Karena peningkatan dalam investasi merupakan indikator dalam penggunaan faktor produksi secara optimal. Sementara itu laju pertumbuhan PMDN tertinggi terjadi pada tahun 1993 sebesar 66,83 persen, namun pada tahun 1996 laju pertumbuhan PMDN negatif 47,12 persen hingga tahun 1997 terjadi krisis ekonomi, kemudian tahun 1998 justru PMDN positif hingga sebesar 59,97 persen dengan total rata-rata PMDN selama 19 tahun sebesar Rp.5.355.099,- Juta.

Selajutya pertumbuhan PMA. di Provinsi Jambi selama 19 tahun terakhir menunjukan pakembangan yang berfluktuasi karena pertumbuhan PMA tersebut menggambarkan adanya kecenderungan pemerintah untuk meningkatkan PMA yang disebabkan kekurangan dari PMDN yang tersedia. Laju pertumbuhan PMA selama tahun 1990 sampai 2008 dengan ratarata pertumbuhan negatif 28,83 persen dimana laju pertumbuhan PMA tertinggi terjadi pada Shim 1996 sebesar 74,78 persen sementara PMA pada tahun 1993 laju pertumbuhannya negatif 621,28 persen, namun pada tahun 1994 dan 1995 pertumbuhan PMA positif 4,09 persen dan 4,67 persen. Kemudian tahun berikutnya menunjukan pertumbuhan positif hingga tahun 1998 sebesar 75,31 persen tetapi tahun 1999 justru negatif sebesar 12,82 persen. 
Pertumbuhan PMA tersebut telah menggambarkan fluktuasi yang terjadi hingga tahun 2007 positif sebear 15,40 persen kemudian tahun 2008 meningkat menjadi sebesar 58,87 persen.

Tabel 1. Perkembangan PMDN dan PMA di Provinsi Jambi Periode 1990-2008

\begin{tabular}{|c|c|c|c|c|}
\hline Tahun & PMDN & $\%$ & PMA & $\%$ \\
\hline 1990 & 342.013 & 0 & 44.352 .231 & 0 \\
\hline 1991 & 543.974 & 37,13 & 46.475 .352 & 4.56 \\
\hline 1992 & 593.211 & 8,30 & 19.024 .012 & -144.29 \\
\hline 1993 & 1.788 .141 & 66,83 & 2.637 .500 & -621.28 \\
\hline 1994 & 2.350 .522 & 23,93 & 2.750 .000 & 4.09 \\
\hline 1995 & 2.620 .648 & 10,31 & 2.885 .000 & 4.67 \\
\hline 1996 & 1.781 .244 & $-47,12$ & 11.440 .783 & 74.78 \\
\hline 1997 & 4.449 .230 & 59,97 & 32.512 .800 & 64.81 \\
\hline 1998 & 5.836 .125 & 23,76 & 131.698 .275 & 75.31 \\
\hline 1999 & 5.692 .327 & $-2,526$ & 116.724 .000 & -12.82 \\
\hline 2000 & 7.296 .560 & 21,97 & 160.764 .225 & 27.39 \\
\hline 2001 & 7.621 .781 & 4,267 & 173.524 .000 & 7.35 \\
\hline 2002 & 8.046 .467 & 5,28 & 149.163 .900 & -16.33 \\
\hline 2003 & 8.371 .161 & 3,88 & 138.919 .115 & -7.37 \\
\hline 2004 & 8.534 .189 & 1,91 & 152.727 .600 & 9.04 \\
\hline 2005 & 8.788 .967 & 2,89 & 179.210 .730 & 14.77 \\
\hline 2006 & 9.128 .0009 & 3,71 & 164.578 .920 & -8.89 \\
\hline 2007 & 9.123 .509 & $-0,05$ & 194.558 .864 & 15.40 \\
\hline 2008 & 8.838 .272 & $-3,23$ & 549.9693 .750 & 64.62 \\
\hline Rata-rata & $5.355 .071,053$ & 11,64 & $119.679 .529,3$ & -23.37 \\
\hline
\end{tabular}

Data di olah : 2010

Pertumbuhan ekonomi merupakan indikator keberhasilan suatu negara, keberhasilan tersebut bersumber dari berbagai faktor yang mempengaruhinya. Salah satu faktor tersebut seperti investasi, karena investasi terdiri dari PMDN dan PMA, dimana PMDN merupakan penanaman modal domestik yang digunakan sebagai penggerak perekonomian suatu bangsa secara mandiri, peningkatan PMDN menggambarkan bahwa investor domestik memiliki kepercayaan tinggi melalui kebijakan pemerintah terhadap kepastian hukum dan keamanan. 
Negara yang penanaman modal nya didominasi investor domestik berarti negara tersebut tidak ketergantungan terhadap negara lain. PMDN diharapkan harus lebih besar dari PMA dimana PMA merupakan invesatsi asing yang cenderung mendominasi semua kebijakan dalam perekonomian. PMA yang lebih besar dari PMDN berarti negara tersebut masih tinggi tingkat ketergantungannya.

Sementara PMDN di provinsi pada tahun 1993 sebesar 66,83 persen dan merupakan pertumbuhan tertinggi selama 19 tahun terakhir yaitu tahun 1990 sampai tahun 2008, namun bersamaan pada tahun tersebut pertumbuhan PMA justru negatif tertinggi yaitu sebesar 621,28. Kemudian laju pertumbuhan PMA tertinggi pada tahun 1996 yaitu sebesar 74,78 persen bersaman tahun tersebut $\mathrm{j}$ ustru pertumbuhan PMDN negatif sebesar 47,12 persen. Pertumbuhan PMDN negatif mengindikasikan bahwa penanaman modal domestik enggan menginvestasikan uangnya sehingga uang yang ada cenderung di tabung. Pada awal tahun 1996 terjadi krisis ekonomi yang menyebabkan ketergantungan terhadap investor asing yang mendominasi hingga puncak krisis ekonomi tahun 1997 sehingga menghancurkan perekonomian bangsa dan daerah, termasuk di Provinsi Jambi.

Faktor-faktor yang mempengaruhi PMDN dan PMA di Provinsi Jambi Periode 19902008.

1. Hasil Perhitungan Faktor-faktor yang mempengaruhi PMDN di Provinsi Jambi Periode 1990-2008

Hasil perhitungan dari penelitian ini mengenai analisis faktor-faktor yang mempengaruhi PMDN di Provinsi Jambi diantaranya dengan menggunakan variabel kurs, suku bunga pinjaman, tingkat upah dan kebijakan pemerintah dari periode 1990-2008 atau selama 19 tahun terakhir dengan menggunakan alat bantu program SPSS 17.0 maka dapat dilihat pada tabel sebagai berikut:

Tabel 2. Hasil perhitungan regresi faktor-faktor yang mempengaruhi PMDN di Provinsi Jambi Periode 1990-2008

\begin{tabular}{|l|r|r|c|c|c|}
\hline \multirow{2}{*}{ Model } & \multicolumn{2}{|c|}{ Unstandardized Coefficien } & $\begin{array}{c}\text { Stadnardized } \\
\text { Coefficeien }\end{array}$ & \multirow{2}{*}{$\mathbf{t}$} & \multirow{2}{*}{ Sig. } \\
\cline { 2 - 4 } & \multicolumn{1}{|c|}{ B } & Stand Error & \multicolumn{1}{c|}{ Beta } & & \\
\hline (Constant) & 491887,845 & 1307010,042 & - & 0,376 & 0,712 \\
\hline $\mathrm{X}_{1}$ SB & $-5639,329$ & 58933,224 & $-0,008$ & $-0,096$ & 0,925 \\
\hline $\mathrm{X}_{2}$ KURS & 689,882 & 62,935 & 0,797 & 10,962 & 0,000 \\
\hline
\end{tabular}




\begin{tabular}{|l|r|r|r|r|r|}
\hline $\mathrm{X}_{3} \mathrm{UPAH}$ & 3,347 & 1,727 & 0,220 & 1,937 & 0,073 \\
\hline $\mathrm{X}_{4} \mathrm{KP}$ & $-226621,789$ & 284382,955 & $-0,033$ & $-0,797$ & 0,439 \\
\hline
\end{tabular}

\section{Dependent Variabel PMDN}

$$
\mathrm{Y}_{\text {PMDN }}=491887,845-5639,329 \beta_{1} \mathrm{X}_{1}+689,8821 \log \beta_{2} \mathrm{X}_{2}+3,347 \log \beta_{3} \mathrm{X}_{3}-226621,789 \beta_{4} \mathrm{X}_{4}
$$

Berdasarkan hasil perhitungan regresi di peroleh konstanta sebesar 491887,845 artinya jika variabel-variabel lain di asumsikan bernilai nol, maka PMDN sama dengan 491887,845. Sementara. nilai konstanta tersebut merupakan nilai fungsi yang digunakan sebagai tolak ukur perubahan variabel independen dalam mempengaruhi perubahan variabel dependen.Selanjutnya nilai koefisien dari perhitungan regresi kurs di peroleh angka sebesar 689,882 artinya jika nilai kurs terapresiasi 1 rupiah, maka nilai PMDN sama dengan 689,882. Secara parsial kurs memiliki pengaruh yang positif terhadap PMDN, artinya jika kurs terapresiasi 1 rupiah maka PMDN meningkat hal itu terindikasi pada nilai beta sebesar 0,797 atau 79,7 persen, serta pengaruh kurs terhadap PMDN sangat signifikan 0,000 -persen dimana standar erornya (a) di bawah 5 persen yaitu 0 persen.

Sementara nilai koefisien regresi dari tingkat upah di peroleh angka sebesar 3,347 artinya jika tingkat upah meningkat 1 persen, maka PMDN sama dengan 3,347. Secara parsial tingkat upah memiliki pengaruh yang positif terhadap nilai PMDN hal tersebut terindikasi pada hasil perhitungan regresi di mana nilai betanya sebesar 0,220 atau 22 persen. Artinya tingkat upah memiliki pengaruh terhadap nilai PMDN sebesar 22 persen dan sangat signifikan, dimana standar erornya (a) di bawah 10 persen yaitu sebesar 0,073 atau 7,3 persen. Tingkat upah memiliki pengaruh terhadap fluktuasi nilai PMDN, dimana tergantung kondisi pasar karena besar kecilnya tingkat upah akan mempengaruhi oleh permintaan dan penawaran. Selain pengaruh pasar, tingkat upah dihitung berdasarkan kondisi ekonomi masyarakat suatu daerah dilihat dari kebutuhan hidup minimum perhari dan diakumulasikan perbulan, sementara itu tingkat upah merupakan langkah pemerintah untuk mensejahterakan masyarakan dalam memenuhi bebutuhan hidup, hal itu terindikasi pada hasil perhitungan dimana tingkat upah tersebut terus mengalami pertumbuhan yang positif pertahun.

Secara determinasi atau secara keseluruhan bahwa semua variable bebas yaitu kurs, suku bunga, tingkat upah, dan kebijakan pemerintah hanya suku bunga dan 
kebijakan pemerintah yang tidak signifikan terhadap variabel dependen yaitu sebesar 0,925 atau 92,5 persen dan 0,439 atau 43,9 persen di atas $\alpha 10$ persen. Sementara itu secara simultan diperoleh perhitungan hasil regresi yang menunjukan tingkat signifikansi F di bawah 5 persen yaitu 0,000 , artinya variabel independen sangat signifikan dalam mempengaruhi variabel dependen serta melihat nilai $\mathrm{R}^{2}$ sebesar 0,975 atau 97,5 persen, artinya perubahan variabel-variabel bebas (independen) mampu mempengaruhi perubahan variabel terikat (dependen) yaitu sebesar 97,5 persen, sedangkan sisanya di pengaruhi oleh variabel lain selain dari variabel dalam penelitian ini. Kemudia nilai $\mathrm{R}$ diperoleh angka sebesar 0,968 atau 96,8 persen yang menunjukkan ; bahwa terdapat pengaruh yang kuat antara variabel independen, dalam hal ini kurs, suku bunga, tingkat upah, dan kebijakan pemerintah.

\section{Hasil Perhitungan Faktor-faktor yang mempengaruhi PMA di Provinsi Jambi}

\section{Periode 1990-2008}

Hasil perhitungan dari penelitian ini mengenai analisis faktor-faktor yang mempengaruhi PMA di Provinsi Jambi diantaranya dengan menggunakan variabel kurs, suku bunga pinjaman, kesempatan kerja, tingkat upah dan kebijakan pemerintah dari periode 1990-2008 atau selama 19 tahun terakhir dengan menggunakan alat bantu program SPSS 17.0 maka dapat dilihat pada tabel sebagai berikut:

Tabel 3 Hasil perhitungan regresi faktor-faktor yang mempengaruhi PMA di Provinsi Jambi Periode 1990-2008

\begin{tabular}{|l|l|l|l|l|l|}
\hline \multirow{2}{*}{ Model } & \multicolumn{2}{|c|}{ Unstandardized Coefficien } & $\begin{array}{c}\text { Stadnardized } \\
\text { Coefficeien }\end{array}$ & \multirow{2}{*}{$\mathbf{t}$} & \multirow{2}{*}{ Sig. } \\
\cline { 2 - 4 } & \multicolumn{1}{|c|}{ B } & Stand Error & Beta & & \\
\hline (Constant) & $-1,9558$ & 1,5148 & - & $-1,291$ & 0,217 \\
\hline $\mathrm{X}_{1}$ KURS & 9394,458 & 7290,076 & 0,289 & 1,289 & 0,218 \\
\hline $\mathrm{X}_{2}$ SB & 6627533,318 & 6826476,554 & 0,256 & 0,971 & 0,348 \\
\hline $\mathrm{X}_{3} \mathrm{UPAH}$ & 466,188 & 200,101 & 0,816 & 2,330 & 0,035 \\
\hline $\mathrm{X}_{4}$ KP & 3,8577 & 3,2947 & 0,152 & 1,171 & 0,261 \\
\hline
\end{tabular}

Dependent Variabel PMA

$\mathrm{Y}_{\mathrm{PMA}}=-1,9558+9394,458 \beta_{1} \mathrm{X}_{1}+6627533,318 \beta_{2} \mathrm{X}_{2}+466,188 \log \beta_{3} \mathrm{X}_{3}+3,8577 \log \beta_{4} \mathrm{X}_{4}$ 
Berdasarkan hasil perhitungan regresi di peroleh konstanta negatif sebesar 1,9558 artinya jika variabel-variabel lain di asumsikan bernilai nol, maka PMA sama dengan 1,9558. Sementara itu nilai konstanta merupakan nilai fungsi yang digunakan sebagai tolak ukur perubahan variabel independen dalam mempengaruhi perubahan variabel dependen. Selanjutnya perhitungan nilai koefisien regresi dari nilai kurs di peroleh angka sebesar 9394,458 artinya jika kurs terdepresiasi 1 rupiah, maka PMA sama dengan 9394,458. Secara parsial kurs memiliki pengaruh yang positif dengan PMA, artinya jika kurs terdepresi 1 Rupiah maka PMA sama dengan 9394,458. Hal itu terindikasi pada hasil regresi di mana nilai betanya sebesar 0,289 atau 28,9 persen. Artinya kurs memiliki pengaruh terhadap PMA sebesar 28,9 persen, namun pengaruh kurs terhadap PMA tidak signifikan dimana standar erornya $(\alpha)$ di atas 10 persen yaitu sebesar 0,218 atau 21,8 persen. Sementara itu pengaruh kurs terhadap PMA ditentukan oleh menguat atau melemahnya nilai tukar kurs sehingga nilai tukar tersebut menjadi dasar dan pertimbangan bagi investor asing untuk menanamkan modalnya. Disatu sisi melemahnya kurs menyebabkan PMA akan mengalir kedalam negeri begitu juga sebaliknya, sehingga peningkatan PMA akan memberikan kontribusinya dalam perekonomian, namun PMA yang dominan akan berdampak dalam penggunaan sektor-sektor dalam perekonomian dikendalikan oleh pihak asing sehingga menyebabkan ketergantungan.

Sementara nilai koefisien regresi dari suku bunga di peroleh angka sebesar 6627533,318 artinya jika suku bunga rneningkat 1 persen, maka PMA sama dengan 6627533,318. Secara parsial suku bunga memiliki pengaruh negatif terhadap PMA, namun berdasarkan hasil perhitungan suku bunga memiliki pengaruh terhadap PMA yang dilihat dari nilai betanya sebesar 0,256 atau 25,6 persen, sedangkan tingkat signifikansinya (tingkat kesalahan) di atas 10 persen yaitu sebesar 0,348 atau 34,4 persen. Kemudian suku bunga berpengaruh negatif terhadap PMA artinya investor asing enggan menanamkan modalnya karena akan berdampak terhadap nilai PMA tersebut, suku buga yang tinggi menyebabkan para pemegang modal cenderung untuk menabung uangnya sehingga tingkat investasi turun.

Selanjutnya nilai koefisien regresi dari tingkat upah di peroleh angka sebesar 466,188 artinya jika tingkat upah meningkat 1 persen, maka PMA sama dengan 466,188. Secara parsial tingkat upah memiliki pengaruh terhadap PMA, hal itu terindikasi pada hasil regresi di mana nilai betanya sebesar 0,816 atau 81,6 persen. Artinya tingkat upah 
memiliki pengaruh terhadap PMA sebesar 81,6 persen dimana tingkat signifikansinya (tingkat kesalahan) di bawah 5 persen yaitu sebesar 0,035 atau 3,5 persen. Sementara itu pengaruh tingkat upah sangat tergantung kepada kebijakan pemerintah yang bertujuan untuk kesejahteraan masyarakat. Sehingga berdasarkan hasil perhitungan regresi nilai koefisien kebijakan pemerintah di peroleh angka sebesar 3,8577 artinya jika terdapat kebijakan pemeritah dalam peningkatan nilai PMA maka PMA tersebut sama dengan 3,8577. Secara parsial kebijakan pemerintah memiliki pengaruh terhadap PMA hal itu terindikasi pada hasil regresi di mana nilai betanya sebesar 0,152 atau 15,2 persen, selanjutnya pengaruh kebijakan pemerintah terhadap PMA tidak signifikan (tingkat kesalahan) di atas 10 persen yaitu sebesar 0,261 atau 26;1 persen. Sementara itu kebijakan pemerintah merupakan salah-satu cara untuk meningkatankan nilai investasi, baik investasi domestik maupun asing.

Secara determinasi atau secara keseluruhan bahwa semua variabel bebas yaitu kurs, suku bunga, tingkat upah, dan kebijakan pemerintah hanya tingkat upah yang signifikan yaitu sebesar 0,035 atau 3,5 persen dimana di bawah $\alpha 5$ persen. Selanjutnya hasil regresi tingkat signifikansi, F sangat signifikan di bawah $\alpha 5$ persen yaitu sebesar 0,000 atau 0 persen sedangkan nilai $\mathrm{R}^{2}=0,765$ atau 76,5 persen. Artinya bahwa perubahan variabel-variabel bebas (independen) mampu mempengaruhi perubahan variabel terikat (dependen) yaitu sebesar 76,5 persen, sedangkan sisanya di pengaruhi oleh variabel lain selain dari variabel dalam penelitian ini. Selanjutnya nilai R sebesar 0,875 atau 87,5 persen yang menunjukkan bahwa terdapat pengaruh yang kuat antara variabel independen, dalam hal ini kurs, suku bunga, tingkat upah, dan kebijakan pemerintah.

\section{Pengaruh PMDN dan PMA terhadap Pertumbuhan Ekonomi dan Kesempatan Kerja di provinsi Jambi Periode 1990-2008}

\section{Pengaruh PMDN terhadap Pertumbuhan Ekonomi di Provinsi Jambi Periode 1990- 2008}

Hasil perhitungan dari penelitian ini mengenai analisis pengaruh PMDN terhadap pertumbuhan ekonomi di Provinsi Jambi periode 1990-2008 atau selama 19 tahun terakhir dengan menggunakan alat bantu program SPSS 17.0 maka dapat dilihat pada tabel sebagai berikut: 
Tabel 4. Hasil Perhitungan regresi pengaruh PMDN terhadap pertumbuhan ekonomi di Provinsi Jambi Periode 1990-2008

\begin{tabular}{|l|r|r|c|c|c|}
\hline \multirow{2}{*}{ Model } & \multicolumn{2}{|c|}{ Unstandardized Coefficien } & $\begin{array}{c}\text { Stadnardized } \\
\text { Coefficeien }\end{array}$ & \multirow{2}{*}{ t } & \multirow{2}{*}{ Sig. } \\
\cline { 2 - 4 } & B & Stand Error & Beta & & \\
\hline (Constant) & 2,3586 & 647646,006 & - & 3,640 & 0,002 \\
\hline PMDN & 253181,919 & 40507,101 & 0,835 & 6,250 & 0,000 \\
\hline
\end{tabular}

Dependent variabel PE

$\mathrm{Y}_{\mathrm{PMDN}}=2,3586+253181,919 \beta_{1} \mathrm{X}_{1}$

Hasil dari perhitungan regresi di peroleh angka sebesar 2,3586 artinya jika variabel-variabel lain di asumsikan bernilai nol, maka pertumbuhan ekonomi sama dengan 2,3586. Sementara itu nilai koefisien regresi dari pertumbuhan ekonomi di peroleh angka sebesar 253181,919 artinya jika PMDN meningkat 1 persen, maka pertumbuhan ekonomi juga naik sebesar 253181,919. Secara parsial PMDN memiliki pengaruh positif terhadap pertumbuhan ekonomi, artinya jika PMDN rneningkat maka pertumbuhan ekonomi juga ikut meningkat serta dengan melihat nilai betanya sebesar 0,835 atau sebesar 83,5 persen. Artinya PMDN memiliki pengaruh terhadap pertumbuhan ekonomi sebesar 83,5 persen pada tingkat signifikansinya (tingkat kesalahan) yang berada di bawah 5 persen yaitu sebesar 0,000 atau 0 persen.

Secara deterrninasi bahwa PMDN memiliki pengaruh terhadap pertumbuhan ekonomi di bawah $\alpha 5$ persen. Hal ini terindikasi pada hasil regresi yang menunjukan tingkat signifikansi $\mathrm{F}$ hitung di bawah $\alpha 5$ persen yaitu 0,000 atau 0 persen sedangkan nilai $\mathrm{R}^{2}=0,697$ atau 69,7 persen. Artinya perubahan PMDN mampu mempengaruhi tingkat pertumbuhan ekonomi yaitu sebesar 69,7 persen, sedangkan sisanya di pengaruhi oleh variabel lain selain dari variabel dalam penelitian ini. Sedangkan nilai R sebesar 0,835 atau 83,5 persen yang menunjukkan bahwa terdapat pengaruh yang antara variabel independen dan dependen kuat.

\section{Pengaruh PMA terhadap Pertumbuhan Ekonomi di Provinsi Jambi Periode 1990-} 2008

Hasil perhitungan dari penelitian ini mengenai analisis pengaruh PMA terhadap pertumbuhan ekonomi di Provinsi Jambi periode 1990-2008 atau selama 19 tahun 
terakhir dengan menggunakan alat bantu program SPSS 17.0 maka dapat dilihat pada tabel sebagai berikut:

Tabe15. Hasil Perhitungan regresi pengaruh PMA terhadap pertumbuhan ekonomi di Provinsi Jambi Periode 1990-2008

\begin{tabular}{|l|c|c|c|c|c|}
\hline \multirow{2}{*}{ Model } & \multicolumn{2}{|c|}{$\begin{array}{c}\text { Unstandardized } \\
\text { Coefficien }\end{array}$} & $\begin{array}{c}\text { Stadnardized } \\
\text { Coefficeien }\end{array}$ & \multirow{2}{*}{ t } & \multirow{2}{*}{ Sig. } \\
\cline { 2 - 6 } & B & Stand Error & Beta & & \\
\hline (Constant) & 7371,083 & 2840,685 & - & 2,595 & 0,019 \\
\hline PMA & 687,144 & 177,671 & 0,684 & 3,868 & 0,001 \\
\hline
\end{tabular}

Dependent variabel PE

$\mathrm{Y}_{\mathrm{PMA}}=7371,083+687,144 \beta_{1} \mathrm{X}_{1}$

Hasil dari perhitungan regresi di peroleh angka sebesar 7371,083 artinya jika variabel-variabel lain di asumsikan bernilai nol, maka pertumbuhan ekonomi sama dengan 7371,083. Selanjutnya nilai koefisien regresi dari PMA terhadap pertumbuhan ekonomi di peroleh angka sebesar 7371,089 artinya jika PMA meningkat 1 persen, maka pertumbuhan ekonomi naik sebesar 7371,089. Secara parsial PMA memiliki pengaruh yang positif terhadap pertumbuhan ekonomi, artinya jika PMA meningkat maka pertumbuhan ekonomi juga meningkat. Hal ini terindikasi pada hasil regresi di mana nilai betanya sebesar 0,684 atau 68,4 persen. Artinya PMA memiliki pengaruh terhadap pertumbuhan ekonomi sebesar 68,4 persen dan juga dapat dilihat pada tingkat signifikansinya (tingkat kesalahan) yang berada di bawah 5 persen yaitu sebesar 0,001 atau 0,1 persen.

Secara determinasi bahwa PMA memiliki pengaruh terhadap pertumbuhan ekonomi. Hal ini terindikasi pada hasil regresi yang menunjukan tingkat signifikansi $\mathrm{F}$ hitung di bawah $\alpha 5$ persen yaitu 0,001 atau 0,1 persen sedangkan nilai $R^{2}=0,468$ atau 46,8 persen. Artinya bahwa perubahan PMA mampu mempengaruhi tingkat pertumbuhan ekonomi yaitu sebesar 46,8 persen, sedangkan sisanya di pengaruhi oleh variabel lain selain dari variabel dalam penelitian ini. Selanjutnya nilai $\mathrm{R}$ sebesar 0,684 atau 68,4 persen yang menunjukkan bahwa terdapat pengaruh yang kuat antara variabel independen dan dependen.

3. Peagaruh PMDN terhadap Kesempatan Kerja di Provinsi Jambi Periode 1990-2008 
Hasil perhitungan dari penelitian ini mengenai analisis pengaruh PMDN terhadap kesempatan kerja di Provinsi Jambi periode 1990-2008 atau selama 19 tahun terakhir dengan menggunakan alat bantu program SPSS 17.0 maka dapat dilihat pada tabel sebagai berikut:

Tabe16. Hasil Perhitungan regresi pengaruh PMDN terhadap kesempatan kerja di Provinsi Jambi Periode 1990-2008

\begin{tabular}{|l|r|r|c|c|c|}
\hline \multirow{2}{*}{ Model } & \multicolumn{2}{|c|}{$\begin{array}{c}\text { Unstandardized } \\
\text { Coefficien }\end{array}$} & $\begin{array}{c}\text { Stadnardized } \\
\text { Coefficeien }\end{array}$ & \multirow{2}{*}{$\mathrm{t}$} & \multirow{2}{*}{ Sig. } \\
\cline { 2 - 4 } & $\mathrm{B}$ & Stand Error & Beta & & \\
\hline (Constant) & $-2,1737$ & 3,3516 & - & $-6,484$ & 0,000 \\
\hline PMDN & 26,243 & 3,228 & 0,892 & 8,129 & 0,000 \\
\hline
\end{tabular}

Dependent variabel KS
$\mathrm{Y}_{\mathrm{PMDN}}=-2,1737+26,243 \beta_{1} \mathrm{X}_{1}$

Hasil dari perhitungan regresi di peroleh angka negatif sebesar 2,1737 artinya jika variabel-variabel lain di asumsikan bernilai nol, maka kesempatan kerja sama dengan 2,1737. Sementara itu nilai koefisien regresi dari PMDN di peroleh angka sebesar 26,243 artinya jika PMDN meningkat 1 persen, maka kesempatan kerja naik sebesar 26,243. Secara parsial PMDN memiliki pengaruh positif terhadap kesempatan kerja, artinya jika PMDN meningkat maka kesempatan kerja juga meningkat. Hal ini terindikasi pada hasil regresi di mana nilai betanya sebesar 0,892 atau 89,2 persen. Artinya PMDN memiliki pengaruh terhadap kesempatan kerja sebesar 89,2 persen dan juga dapat dilihat pada tingkat signifikansinya (tingkat kesalahan) yang berada di bawah 5 persen yaitu sebesar 0,000 atau 0 persen.

Secara determinasi bahwa PMDN memiliki pengaruh terhadap kesempatan kerja. Hal ini terindikasi pada hasil regresi yang menunjukan tingkat signifikansi $F$ hitung di bawah $\alpha 5$ persen yaitu 0,000 atau 0 persen sedangkan nilai $\mathrm{R}^{2}=0,795$ atau 79,5 persen. Artinya bahwa perubahan PMDN mampu mempengaruhi perubahan tingkat kesempatan kerja yaitu sebesar 79,5 persen, sedangkan sisanya di pengaruhi oleh variabel lain selain dari variabel dalam penelitian ini. Selanjutnya nilai R sebesar 0,892 atau 89,2 persen yang menunjukkan bahwa terdapat pengaruh yang kuat antara variabel independent dan dependent.

4. Pengaruh PMA terhadap Kesempatan Kerja di Provinsi Jambi Periode 1990-2008 
Hasil perhitungan dari penelitian ini mengenai analisis pengaruh PMA terhadap kesempatan kerja di Provinsi Jambi periode 1990-2008 atau selama 19 tahun terakhir dengan menggunakan alat bantu program SPSS 17.0 maka dapat dilihat pada tabel sebagai berikut:

Tabel 7. Hasil Perhitungan regresi pengaruhi PMA terhadap kesempatan kerja di Provinsi Jambi Periode 1990-2008

\begin{tabular}{|l|r|r|c|c|c|}
\hline \multirow{2}{*}{ Model } & \multicolumn{2}{|c|}{$\begin{array}{c}\text { Unstandardized } \\
\text { Coefficien }\end{array}$} & $\begin{array}{c}\text { Stadnardized } \\
\text { Coefficeien }\end{array}$ & \multirow{2}{*}{$\mathrm{t}$} & \multirow{2}{*}{ Sig. } \\
\cline { 2 - 4 } & \multicolumn{1}{|c|}{ B } & Stand Error & Beta & & \\
\hline (Constant) & $-6,2948$ & 2,0998 & - & $-2,998$ & 0,008 \\
\hline PMA & 725,844 & 202,235 & 0,657 & 3,589 & 0,002 \\
\hline
\end{tabular}

Dependent variabel KS

$\mathrm{Y}_{\mathrm{PMDN}}=-6,2948+725,844 \beta_{1} \mathrm{X}_{1}$

Hasil dari perhitungan regresi di peroleh angka negatif sebesar 6,2948 artinya jika variabel-variabel lain di asumsikan bernilai nol, maka kesempatan kerja sama dengan 6,2948. Selanjutnya nilai koefisien regresi dari PMA di peroleh angka sebesar 725,844 artinya jika PMA meningkat 1 persen, maka kesempatan kerja sebesar 725,844. Secara parsial PMA memiliki pengaruh yang positif terhadap kesempatan kerja. Hal ini terindikasi pada hasil regresi di mana nilai betanya sebesar 0,657 atau 65,7 persen. Artinya PMA memiliki pengaruh terhadap kesempatan kerja sebesar 65,7 persen, sedangkan pengaruh PMA terhadap kesempatan kerja sangat signifikan dimana tingkat kesalahannya di bawah 5 persen yaitu sebesar 0,002 atau 0,2 persen.

Secara determinasi bahwa PMA memiliki pengaruh positif terhadap kesempatan kerja. Hal ini terindikasi pada hasil regresi yang menunjukan tingkat signifikansi $\mathrm{F}$ hitung di atas $\alpha 5$ persen yaitu 0,199 atau 19,9 persen sedangkan nilai $\mathrm{R}^{2}=0,095$ atau 9,5 persen. Artinya perubahan tingkat PMA mampu mempengaruhi perubahan tingkat kesempatan kerja sebesar 9,5 persen, sedangkan sisanya di pengaruhi oleh variabel lain selain dari variabel dalam penelitian ini. Selanjutnya nilai $\mathrm{R}$ sebesar 0,308 atau 30,8 persen yang menunjukkan bahwa terdapat pengaruh yang lemah antara variabel independen dan dependen. 


\section{KESIMPULAN DAN SARAN}

\section{Kesimpulan}

Berdasarkan hasil pembahasan di atas maka dapat di tarik kesimpulan yang perlu di kemukakan dalam penulisan ini adalah sebagai berikut:

1. Hasil dari perhitungan dalam penulisan ini bahwa PMDN dan PMA telah menunjukkan pertumbuhan yang berfluktuasi selama 19 tahun terakhir dari tahun 1990 sampai tahun 2008. Sementara itu pertumbuhan PMDN tertinggi terjadi pada tahun 1993 yaitu sebesar 66,83 persen sedangkan pertumbuhan terendah terjadi pada tahun 1996 negatif sebesar 47,12 persen dengan rata-rata pertumbuhan PMDN selama 19 tahun tersebut sebesar 11,64 persen. Secara keseluruhan pertumbuhan PMDN tersebut mengalami pertumbuhan yang positif itu artinya PMDN merupakan faktor dominan dalam mempengaruhi pertumbuhan ekonomi di Provinsi Jambi. Selanjutnya pertumbuhan PMA tertinggi terjadi pada tahun 1998 yaitu sebesar 75,31 persen sedangkan pertumbuhan terendah terjadi pada tahun 1993 yaitu negatif sebesar 621,28 persen dengan rata-rata pertutnbuhan PMA selama 19 tahun terakhir sebesar negatif 23,37 persen.

2. Uji secara keseluruhan di temui bahwa faktor kurs, suku bunga pinjaman, tingkat upah dan kebijakan pemerintah berpengaruh secara bersama-sama terhadap PMDN dan PMA di Provinsi Jambi sangat signiftkan dan bahkan di bawah alpa 5 persen yaitu sebesar 0,000 atau 0 persen. Namun pengujian secara sendiri-sendiri (parsial test) faktor yang mempengaruhi PMDN hanya kurs, dan tingkat upah yang hanya signifikan yaitu masingmasing dibawah alpa 5 sampai 10 persen sedangkan faktor yang mempengaruhi PMA hanya tingkat upah yang signifikan yaitu sebesar 3,5 persen.

3. Pengaruh PMDN dan PMA terhadap pertumbuhan ekonomi dan kesempatan kerja di Provinsi Jambi selama 19 tahun terakhir dari tahun 1990 sampai tahun 2008 dengan melihat pengaruh antara variabel independen dengan variabel dependen, dimana pengaruh PMDN dan PMA terhadap pertumbuhan ekonomi sebesar 83,5 dan 68,4 pesen dengan tingkat signifikansinya masing-masing dibawah alpa 5 persen yaitu 0 dan 0,1 persen serta pengaruh PMDN dan PMA terhadap kesempatah kerja sebesar 89,2 dan 65,7 persen dengan tingkat signifikansinya masing-masing dibawah alpa 5 persen 0 persen yaitu 0 dan 0,2 persen. 


\section{Saran}

Berdasarkan kesimpulan di atas maka saran yang dikemukan dalam penulisan ini adalah sebagai berikut:

1. Diharapkan PMDN dan PMA dapat menunjukkan pertumbuhan yang positif karena pertumbuhan tersebut berindikasi kondisi perekonomian mengalami peningkatan yang lebih baik sehingga dapat mempengaruhi peningkatan tingkat pendapatan masyarakat.

2. Diharapkan pemerintah dapat menjaga stabilitas nilai kurs tukar, suku bunga pinjaman, tingkat upah dan mengendalikan kebijakan yang bersifat kondusif dalam upaya meningkatkan nilai PMDN dan PMA di Provinsi Jambi.

3. Pemerintah diharapkan dapat mengarahkan sektor-sektor ekonomi yang potensial sehingga berdampak besar terhadap pertumbuhan ekonomi dan kesempatan kerja yang di fasilitasi bagi investor PMDN dan PMA dalam berinvestasi.

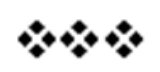

\section{DAFTAR PUSTAKA}

Anonim, 2007. Pengertian, Jenis, dan Macam Pengangguran. Google.com ,2009. Analisis Data Pengangguran di Indonesia. Google.com.

Amir Amir, (2007) Perekonomian Indonesia. Fe Unja. Jambi.

Djojohadikusumo, (1994). Perekonomian Indonesia. Pt Raja Grafindo Persada, Jakarta.

Lipsey, (1992). Ekonomi Pembangunan. Erlangga, Jakarta.

Madura, (2000). Teori Ekonomi. Erlangga, Jakarta.

Makiw N. Gregory, 2000. Teori Makro, Ed-4.Harvard University. Erlangga, Jakarta.

Manurung, 2002. Ilmu Ekonomi, FE UI, Jakarta.

Krugman, (2000). Pembangunan Ekonomi Dan Tingkat Kemajuan Ekonomi Indonesia, FUMI, Jakarta.

Salvatore, (1.997). Teori Kurs. PT Raja Grafindo Persada, Jakarta.

Sukirno Sadono, 2005. Makro Ekonomi (Teori Pengantar), PT Raja Grafindo Persada, Jakarta. 
Suparmoko, 1999. Ekonomi Pembangunan, BP FE-UGM, Yogyakarta.

Tandelin Firdaus, 2001. Analisis Investasi dan Manajemen, PT BP FE, Jakarta.

Tan Syamsurijal, 2003. Ekonomi Internasional. FE. LTNJA. Jambi

Todaro P Michael, 2003. Ekonomipembangunan. Erlangga, Jakarta.

Yulmardi dkk, (1998). Struktur Penyerapan Tenaga Kerja. FE. UNJA 